\title{
Ustalanie stron postępowania w spawach o nałożenie administracyjnej kary pieniężnej za zajęcie pasa drogowego w orzecznictwie sądów administracyjnych
}

The determination of the parties to proceedings in the cases imposing a administrative monetary penalties for occupation of road lane without permission in the spotlight of administrative courts rulings

\section{STRESZCZENIE}

Podmiot, który dopuszcza się bezprawnego zajęcia pasa drogowego bez stosownego zezwolenia, bądź posiadając takie zezwolenie przekracza określony w nim termin zajęcia bądź jego powierzchnię, podlega odpowiedzialności administracyjnej w postaci administracyjnej kary pieniężnej. Jedną z pierwszych czynności, która poprzedza wszczęcie postępowania zmierzającego do nałożenia kary pieniężnej jest ustalenie podmiotu, który dopuścił się deliktu administracyjnego. Problematyka ustalania strony postępowania wszczynanego na podstawie art. 40 ust. 12 ustawy o drogach publicznych była wielokrotnie przedmiotem zainteresowania sądów administracyjnych. W pracy przedstawione zostały poglądy wyrażane przez wojewódzkie sądy administracyjne oraz Naczelny Sąd Administracyjny odnoszące się do ustalenia strony, która powinna ponieść odpowiedzialność za nielegalną ingerencję w substancję pasa drogowego.

Słowa kluczowe: administracyjna kara pieniężna, drogi publiczne, strona postępowania 


\section{UWAGI WPROWADZAJĄCE}

Zgodnie z art. 28 k.p.a. ${ }^{1}$ stroną postępowania jest każdy, czyjego interesu prawnego bądź obowiązku dotyczy postępowanie albo kto żąda czynności organu ze względu na swój interes prawy lub obowiązek. W literaturze wskazuje się, że przepis ten wyraża dwie normy: pierwsza $z$ nich wskazuje, że stroną jest ten, kto uznaje się za legitymowanego do udziału w postępowaniu administracyjnym; uważa, że posiada interes prawny lub obowiązek w danej sprawie, a także dokonuje czynności wniesienia żądania wszczęcia postępowania administracyjnego; druga z nich wskazuje, że stroną postępowania będzie każdy, kto zgodnie z przekonaniem wszczynającego z urzędu postępowanie organu administracji publicznej ma interes prawny lub obowiązek, którego dotyczyć będzie wszczynane przez niego postępowanie ${ }^{2}$. Podnosi się, że bez strony nie może istnieć postępowanie administracyjne, tak samo strona nie istnieje bez tego postępowania (tj. poza nim) ${ }^{3}$. Na przestrzeni lat $\mathrm{w}$ doktrynie wykształciły się dwie koncepcje postrzegania legitymacji procesowej strony postępowania: subiektywną oraz obiektywną. Koncepcja subiektywna (zwana inaczej formalną lub procesową) zakłada, że pojęcie strony w istocie sprowadza się do zagwarantowania każdemu możliwości zaspokojenia jego roszczenia ${ }^{4}$. E. Iserzon wskazywał, że art. 28 k.p.a. „ujmuje pojęcie strony w sposób prosty, jasny i logiczny, gwarantując osobom, które w ich mniemaniu mają niezaspokojone roszczenie prawne, możliwość uzyskania ich zaspokojenia", dlatego też organy administracji publicznej nie powinny badać tego, czy interes prawny lub obowiązek, na który powołuje się strona opiera się na rzeczywistym interesie prawnym lub obowiązku i nie mogą odmówić wszczęcia postępowania powołując się na ich brak'. Natomiast obiektywna (materialna) koncepcja sprowadza się do stwierdzenia, że stroną może zostać wyłącznie ten podmiot, który na podstawie przepisów prawa materialnego posiada legitymację do podejmowania jakichkolwiek inicjatyw procesowych. J. Borkowski zauważył, że za koncepcją tą przemawia w szczególności: konieczność jednakowego traktowania czynności postępowania wszczynanego na wniosek jak i z urzędu, gdyż w obu przypadkach należy ustalić stronę; konieczność uwzględnienia właściwości organów admi-

1 Ustawa z dnia 14 czerwca 1960 r. - Kodeks postępowania administracyjnego (Dz.U. z 2017 r., poz. 1257 z późn. zm., dalej: „k.p.a.”).

2 J. Borkowski, B. Adamiak (w:) B. Adamiak, J. Borkowski, Kodeks postępowania administracyjnego. Komentarz, Warszawa 2017, s. 228-230, A. Wróbel (w:) A. Wróbel, M. Jaśkowska (red.), Kodeks postępowania administracyjnego. Komentarz, Warszawa 2016, s. 231-229.

3 P.Gołaszewski (w:) R. Hauser, M. Wierzbowski (red.), Kodeks postepowania administracyjnego. Komentarz, Warszawa 2017, s. 228, A. Wróbel, Kodeks ..., s. 225.

4 P. Gołaszewski, Komentarz..., s. 236.

5 E. Iserzon (w:) E. Iserzon, J. Starościak, Kodeks postępowania administracyjnego. Komentarz, Warszawa 1970, s. 90-91. 
nistracji publicznej, gdyż tylko interes prawny strony umożliwia identyfikację właściwego organu; potrzeba poszanowania zasady ekonominiki procesowej, gdyż postępowanie winno być od samego początku dążyć do rozstrzygnięcia sprawy co do istoty ${ }^{6}$. Jedyną przesłanką, która decyduje o uzyskaniu przez dany podmiot przymiotu strony w postępowaniu jest legitymowanie się interesem prawnym lub obowiązkiem.

Jednym z obowiązków organów prowadzących postępowania administracyjne jest ustalenie stron postępowania (niezależnie od tego, czy postępowanie wszczynane jest z urzędu czy na żądanie). Poprawne i właściwe określenie kręgu stron w rozumieniu art. 28 k.p.a. warunkuje w sposób niebudzący wątpliwości prawidłowość całego postępowania administracyjnego i musi dotyczyć każdego jego etapu. Przyjmuje się, czynność ta powinna być co do zasady jednym z pierwszych zadań podejmowanych przez organ po wszczęciu postępowania (tak, by zapewnić wszystkim jego stronom czynny udział już od początkowego etapu sprawy). Dlatego też organ prowadzący postępowanie w sprawie powinien dążyć do takiego ustalenia stanu faktycznego, który pozwoli na bezsporne wskazanie podmiotów, których interesu prawnego lub obowiązku postępowanie dotyczy. Niewłaściwe ustalenie stron postępowania stanowi naruszenie przepisów procedury administracyjnej, co może stanowić podstawę do wznowienia postępowania (art. $145 \S 1$ pkt 4 k.p.a.) lub stwierdzenia nieważności decyzji (art. $156 \S 1$ pkt 4 k.p.a.).

\section{PODSTAWOWE ELEMENTY KONSTRUKCJI KARY PIENIĘŻNEJ ZA ZAJĘCIE PASA DROGOWEGO BEZ ZEZWOLENIA}

Pas drogowy drogi publicznej jest przestrzenią szczególną, gdyż ma ona przede wszystkim umożliwić prowadzenie w niej ruchu drogowego. Za jego pośrednictwem administracja publiczna może realizować powierzone jej zadania w sferze transportu, komunikacji i przemieszczania się. Jest to składnik majątku publicznego niezbędny dla zaspokajania powszechnych potrzeb społeczeństwa, a także niezbędny element rozwoju handlu czy bezpieczeństwa wewnętrznego państwa. Pas drogowy, będący dobrem publicznym, został przez ustawodawcę objęty szczególną ochroną wyrażoną w ustawie z dnia 21 marca 1985 r. o drogach publicznych ${ }^{7}$. Przejawem tej ochrony jest generalny zakaz dokonywania w pasie drogowym czynności, które mogłyby powodować zniszczenie lub uszkodzenie drogi i jej urządzeń, zmniejszenie jej trwałości czy powodowałoby zagrożenie w pasie drogowym (art. 39 u.d.p.), natomiast jedną z zakazanych przez ustawodawcę czynności

6 J. Borkowski (w:) J. Borkowski (red.), Kodeks postepowania administracyjnego. Komentarz, Warszawa 1989, s. 113.

7 Tekst jedn. Dz.U. z 2017 r., poz. 2222 z późn. zm., dalej: „u.d.p.”. 
jest zajmowanie pasa drogowego na cele niezwiązane z budową, przebudową, remontem, utrzymaniem i ochroną dróg. Zgodnie z art. 40 ust. 12 u.d.p. zajęcie pasa drogowego w celach niedrogowych bez stosownego zezwolenia zarządcy drogi sankcjonowane jest administracyjną karą pieniężną.

Administracyjna kara pieniężna jest jedną z możliwych form sankcjonowania deliktów administracyjnych ${ }^{8}$. Rozumiana jest jako pewna dolegliwość finansowa zadawana podmiotowi niedopełniającemu nałożonego na niego obowiązku, nakazu lub zakazu ${ }^{9}$. Kary pieniężne postrzegane są jako narzędzia władztwa administracyjnego, które nie stanowią konsekwencji dopuszczenia się czynu zabronionego, lecz stosowane są w skutek powstania stanu niezgodności z prawem ${ }^{10}$. Odpowiedzialność administracyjna, w ramach której są one nakładane jest zobiektywizowana i oderwana od pojęcia winy, dlatego też sam fakt popełnienia deliktu administracyjnego zobowiązuje właściwy organ administracji publicznej do nałożenia kary pieniężnej. Jednocześnie podnosi się, iż karany podmiot powinien mieć możliwość uwolnienia się od poniesienia kary pieniężnej poprzez wykazanie, że podjął on wszystkie możliwe działania i środki, które miałyby zapobiec powstaniu stanu niezgodności z prawem ${ }^{11}$, czy też niedopełnienie obowiązku (nakazu lub zakazu) miało miejsce w konsekwencji okoliczności, za które nie powinien ponosić odpowiedzialności ${ }^{12}$. Administracyjne kary pieniężne nakładane są $\mathrm{w}$ drodze decyzji administracyjnej w trybie przepisów k.p.a. zarówno na osoby fizyczne, jak i osoby

${ }^{8}$ Przedstawiciele doktryny, obok administracyjnych kar pieniężnych, wyróżniają w szczególności sankcje pozbawienia bądź ograniczenia uprawnienia oraz sankcje o charakterze egzekucyjnym (por. M. Wincenciak, Sankcje w prawie administracyjnym i procedura ich wymierzania, Warszawa 2008, s. 94-95, 106-117). Inne klasyfikacje sankcji administracyjnych zaproponowali m.in. H. Nowicki (por. H. Nowicki (w:) R. Hauser, Z. Niewiadomski, A. Wróbel (red.), System prawa administracyjnego t.7, Warszawa 2012, s. 636-641) czy E. Kruk (por. E. Kruk, Sankcja administracyjna, Lublin 2013, s. 173-218).

${ }^{9}$ E. Kruk, Sankcja..., s. 182.

${ }^{10}$ Wyrok WSA w Olsztynie z dnia 24 czerwca 2014 r., II SA/Ol 419/14, Legalis nr 1152542, wyrok TK z dnia 31 marca 2006 r., SK 75/06, Legalis nr 95189.

11 Wyrok WSA w Kielcach z dnia 20 lipca 2017 r., II Sa/Ke 289/17, LEX nr 2359721, wyrok Naczelnego Sądu Administracyjnego z dnia 29 czerwca 2011 r., II GSK 648/10, Legalis nr 372982 i powołane tam orzecznictwo Trybunału Konstytucyjnego.

12 Wyrok TK z dnia 1 marca 1994 r., U 7/93, Legalis nr 10199. W uzasadnieniu wyroku Trybunał przedstawił przykładowy katalog okoliczności uwalniających od odpowiedzialności, do których zaliczył: działanie siły wyższej, stan wyższej konieczności, działanie osób trzecich, za które karany podmiot nie odpowiada). Na okoliczności takie wskazywały również sądy administracyjne. Wyrok NSA z dnia 10 marca 2011 r., II GSK 244/10, LEX nr 1244617 („Nie powinno być przeszkód dla odpowiedniego stosowania okoliczności egzoneracyjnych w odniesieniu do odpowiedzialności obiektywnej z tytułu naruszenia ustawowych przepisów sankcjonowanych sankcją administracyjną. W przeciwnych przypadku mogłoby dochodzić do trudnej do zaakceptowania nadmiernej i nieuzasadnionej ze społecznego punktu widzenia surowości odpowiedzialności podmiotu za zdarzenia, na których zaistnienie nie miał jakiegokolwiek wpływu, nawet przy zachowaniu najwyższej staranności"). 
prawne oraz jednostki organizacyjne nieposiadające osobowości prawnej, a decyzja ta podlega sądowej kontroli pod względem zgodności z prawem sprawowanej przez sądy administracyjne ${ }^{13}$.

Karę pieniężną wskazaną $\mathrm{w}$ art. 40 ust. 12 u.d.p. nakłada się, o ile podmiot dopuszczający się zajęcia pasa drogowego nie legitymuje się stosownym zezwoleniem, bądź posiadając takie zezwolenie przekroczy określony w nim czas zajęcia bądź jego powierzchnię ${ }^{14}$. Działania, które mogą stanowić podstawę do nałożenia sankcji wskazane zostały przez ustawodawcę w art. 40 ust. 2 u.d.p. i zalicza się do nich: prowadzenie robót w pasie drogowym, umieszczenie w pasie drogowym urządzeń infrastruktury technicznej niezwiązanych z potrzebami zarządzania drogami lub potrzebami ruchu drogowego, umieszczanie w pasie drogowym obiektów budowlanych niezwiązanych z potrzebami zarządzania drogami lub potrzebami ruchu drogowego oraz reklam, a także inne niż wskazane zajęcie pasa drogowego na zasadzie wyłączności ( $\mathrm{w}$ tym zajęcie w celu usunięcia awarii). Organem właściwym do nałożenia kary pieniężnej jest zarządca drogi. Zgodnie z art. 19 ust. 2 u.d.p. zarządcami dróg są: dla dróg krajowych - Generalny Dyrektor Dróg Krajowych i Autostrad, dla dróg wojewódzkich - zarząd województwa, dla dróg powiatowych - zarząd powiatu, dla dróg gminnych - wójt (burmistrz, prezydent miasta), przy czym w mieście na prawach powiatu zarządcą wszystkich dróg, prócz autostrad i dróg ekspresowych, jest prezydent miasta. Kara pieniężna jest

${ }^{13}$ L. Klat - Wertelecka, Sankcja egzekucyjna $w$ administracji a kara administracyjna (w:) M. Stahl, R. Lewicka, M. Lewicki (red.), Sankcje administracyjne. Blaski i cienie, Warszawa 2011, s. $70-71$.

${ }^{14}$ Nadmienić należy, że takie same skutki prawne jak zajęcie pasa drogowego bez zezwolenia nieść będzie zajęcie pasa drogowego bez stosownej umowy cywilnoprawnej, o której jest mowa w art. 22 ust. 2, 2a i 2 c u.d.p. Zgodnie $\mathrm{z}$ art. 22 ust. 2 u.d.p. grunty znajdujące się w nieodpłatnym trwałym zarządzie zarządcy drogi mogą na podstawie umowy cywilnoprawnej zostać wynajęte, wydzierżawione lub użyczone na cele związane z potrzebami zarządzania drogami, potrzebami ruchu drogowego lub obsługi użytkowników ruchu, a także na cele instalacji stacjonarnych i przenośnych urządzeń służących do obserwacji i rejestracji obrazu zdarzeń na drogach (art. 29g ust. 1 u.d.p.). Z tytułu zawartej umowy cywilnoprawnej zarządca drogi może pobierać opłatę określoną w tejże umowie. Możliwe jest także przekazanie w najem, dzierżawę lub użyczenie gruntów znajdujących się w pasie drogowym partnerowi prywatnemu nap odstawie umowy o partnerstwie publiczno - prywatnym (art. 22 ust. 2a u.d.p.) w celach wykonywania działalności gospodarczej. W granicach miasta na prawach powiatu zarządca drogi może w drodze odpłatnej umowy cywilnoprawnej dopuścić umieszczenie na gruntach znajdujących się w pasie drogowym tablic reklamowych i urządzeń reklamowych, o ile jest to uzasadnione względami funkcjonalnymi, w szczególności jeżeli reklamy takie znajdują się na wiatach przystankowych lub na obiektach małej architektury (art. 22 ust. $2 \mathrm{c}$ u.d.p.). Konstrukcja taka daje zarządcom dróg możliwość wyboru sposobu udostępnienia pasa drogowego przedsiębiorcom: $\mathrm{z}$ jednej strony mogą oni dopuszczać ingerencję w substancję pasa drogowego w trybie administracyjnoprawnym, zaś z drugiej strony w trybie cywilnoprawnym, przy czym wybór jednej z nich wyklucza możliwość skorzystania z drugiej. 
nakładana w formie decyzji administracyjnej po przeprowadzeniu postępowania jurysdykcyjnego postępowania administracyjnego.

Jednocześnie zauważyć należy, że nie każde zajęcie pasa drogowego jest przez ustawodawcę sankcjonowane. Zajęcie pasa drogowego na cele drogowe rozumieć można jako: „zajęcie w celu umieszczenia w nim obiektów budowlanych i urządzeń związanych $\mathrm{z}$ istnieniem oraz funkcjonowaniem drogi, gospodarką drogową lub obsługą ruchu drogowego, a także w celu podjęcia innych działań w tym zakresie"15.

Taka forma zajęcia jest oczywistą konsekwencją zadań powierzonych zarządcom dróg (art. 19 ust. 1 i art. 20 u.d.p.) i zwolnione jest obowiązku uprzedniego uzyskania zezwolenia na zajęcie pasa drogowego. Dlatego też zajęcie pasa przez zarządcę w celu budowy, przebudowy, remontu drogi czy umieszczania w granicach pasa drogowego obiektów i urządzeń niezbędnych do prawidłowego i skutecznego utrzymania drogi oraz zapewnienia maksymalnego bezpieczeństwa w jej granicach (por. rozporządzenie Ministra Transportu i Gospodarki Morskiej z dnia 2 marca 1999 r. w sprawie warunków technicznych, jakim powinny odpowiadać drogi publiczne i ich usytuowanie $\left.{ }^{16}\right)$.

\section{STRONA POSTĘPOWANIA W SPRAWIE NAŁOŻENIA KARY PIENIĘŻNEJ ZA ZAJĘCIE PASA DROGOWEGO BEZ ZEZWOLENIA}

Postępowanie w przedmiocie nałożenia kary pieniężnej za zajęcie pasa drogowego bez zezwolenia realizuje zasadę oficjalności i to na zarządcy drogi ciąży obowiązek właściwego ustalenia podmiotu, który dopuścił się bezprawnej ingerencji w granice pasa drogowego. Żaden z przepisów u.d.p. nie wskazuje expressis verbis na cechy podmiotu, który powinien uzyskać przymiot strony postępowania. Nie miej jednak przyjmuje się, że za stroną postępowanie będzie każdorazowo podmiot, który faktycznie zajmuje pas drogowy ${ }^{17}$. Dla uznania danego pomiotu za stronę wystarczające jest, by podmiot ten swoim zachowaniem wyczerpał znamiona działania wskazane w art. 40 ust. 12 u.d.p., bądź też znamiona te wypełnił iy podmiot, o ile można przypisać mu takie zachowanie bądź jego skutek ${ }^{18}$. Za niedopuszczalne przyjmuje się automatyczne uznawanie za stronę postępowania podmiotu, który w opinii zarządcy drogi winien był wystąpić o wydanie zezwolenia na zajęcie pasa drogowe, ponieważ w pierwszej kolejności zarządca obowiązany jest do ustalenia

${ }^{15}$ K. Sobieralski, Kara za zajęcie pasa drogowego, Wrocław 2015, s. 59.

16 Tekst jedn. Dz.U. z 2016 r., poz. 124.

17 Wyrok NSA z dnia 9 czerwca 2015 r., II GSK 1023/14, Legalis 1311855, wyrok WSA w Gorzowie Wielkopolskim z dnia 28 lutego 2018 r., II SA/Go 1162/17, LEX nr 2455892, wyrok WSA w Gorzowie Wielkopolskim z dnia 21 czerwca 2017 r., II SA/Go 320/17, Legalis nr 1624885, wyrok NSA z dnia 23 czerwca 2015 r., II GSK 1377/14, LEX nr 1982581.

18 Wyrok WSA w Poznaniu z dnia 14 stycznia 2015 r., III SA/Po 537/14, 
stanu faktycznego sprawy zajęcia, a dopiero po tym, gdy dokonujący zajęcia pasa drogowego nie wylegitymuje się stosownym zezwoleniem zarządcy drogi lub nie wykaże, że zajęcie nie odpowiada żadnemu z przypadków ujętych w art. 40 ust. 12 u.d.p. (tzn. nie było to zajęcie w celu prowadzenia robót w pasie drogowym, umieszczania w nim urządzeń infrastruktury technicznej, obiektów budowlanych lub reklam, bądź zajęcie na zasadzie wyłączności ${ }^{19}$ możliwe jest orzekanie o jego odpowiedzialności ${ }^{20}$. Stroną postępowanie nie może być natomiast podmiot, który mógłby potencjalnie zajmować pas drogowy, jednakże faktycznie tego nie uczynił, ponieważ bez znaczenia jest to, jaki podmiot uzyskał decyzję o warunkach zabudowy, czy też o pozwoleniu na budowę obiektu, ponieważ dla wymierzenia kary pieniężnej istotne jest, kto dokonał faktycznego zajęcia pasa drogowego na cele niezwiązane z ruchem drogowym, bez uzyskania zezwolenia, o którym jest mowa w art. 40 ust. 1 i 2 u.d.p. ${ }^{21}$.

W przypadku umieszczenia $\mathrm{w}$ granicach pasa drogowego urządzeń infrastruktury technicznej, obiektów budowlanych przymiot strony uzyskują te podmioty, które są właścicielami takich obiektów lub urządzeń ${ }^{22}$, przy czym nie w każdym przypadku to właściciel powinien ponosić odpowiedzialność, ponieważ:

Rozstrzygnięcie kwestii podmiotowej i przedmiotowej odpowiedzialności za zajęcie pasa drogowego wymaga analizy wszystkich okoliczności danej sprawy, w tym również stosunku prawnego łączącego właściciela urządzenia z podmiotem, w którego posiadaniu rzecz ta się znajduje ${ }^{23}$.

Zauważa się także, że w konkretnym stanie faktycznym może okazać się, że to nie właściciel obiektu powinien być podmiotem kary pieniężnej wymierzonej za samowolne zajęcie pasa drogowego. chodzi w szczególności o sytuację, gdy zostanie wskazane, że osobą, która faktycznie dokonała zajęcia pasa drogowego przez umieszczenie określonego obiektu, jest osoba inna, niż właściciel tego obiektu, a okoliczności sprawy nie pozwalają na obciążenie właściciela odpowiedzialnością za działanie takiej osoby ${ }^{24}$.

Co więcej, nieuzasadnione byłoby uznawanie za stronę postępowania podmiotu tylko z uwagi na fakt legitymowania się prawem własności do nieruchomości, gdy faktycznego zajęcia pasa drogowego dopuścił się zupełnie inny podmiot bez wiedzy właściciela ${ }^{25}$. Słusznie podnosi, się że art. 40 ust. 12 u.d.p. nie wiąże kary pieniężnej za zajęcie pasa drogowego z konkretnym podmiotem, to przyjąć trzeba,

19 Wyrok WSA w Szczecinie z dnia 15 stycznia 2015 r., II SA/Sz 993/14, LEX nr 1625552.

${ }^{20}$ Wyrok WSA we Wrocławiu z dnia 21 lipca 2011 r., III SA/Wr 227/11, LEX nr 950752.

${ }^{21}$ Wyrok WSA w Łodzi z dnia 22 października 2008 r., III SA/Łd 272/08, LEX nr 511394.

22 Wyrok NSA z dnia 3 grudnia 2008 r., II GSK 560/08, LEX nr 518207, wyrok WSA w Warszawie z dnia 29 listopada 2017 r., VI SA/Wa 1061/17, LEX nr 2419335.

${ }^{23}$ Wyrok WSA w Gorzowie Wielkopolskim z dnia 21 czerwca 2017 r., LEX nr 2313720.

${ }^{24}$ Wyrok WSA w Łodzi z dnia 14 sierpnia 2014 r., III SA/Łd 314/14, LEX nr 1502814.

${ }^{25}$ Wyrok WSA w Olsztynie z dnia 8 marca 2012 r., II SA/Ol 1049/11, LEX nr 1138650. 
że mogą nim być różne osoby, które w konkretnej sytuacji dokonują bezprawnego zajęcia pasa drogowego. Zatem może być to osoba faktycznie naruszająca pas drogowy, nawet niekiedy wykonawca robót budowlanych w tym pasie albo podmiot, na rzecz którego wykonano roboty, a on posiada do gruntu położonego w pasie stosowny tytuł prawny ${ }^{26}$.

Dla uznania danego podmiotu za stronę postępowania nie ma żadnego znaczenia to, czy podmiot ten zajmuje pas drogowy poprzez umieszczanie w nim swojej bądź cudzej rzeczy ${ }^{27}$, a „zajęcie przez zidentyfikowany podmiot pasa drogowego, poprzez składowanie w nim określonych przedmiotów ma miejsce niezależnie od tego, czy złożone przedmioty stanowią jego własność" 28 .

Jeżeli zarządca drogi ma wątpliwości, co do podmiotu, który jest faktycznie właścicielem umieszczonej w pasie drogowym reklamy (np. w postaci zaparkowanego w granicach pasa auta okrytego plandeką z lokowaną treścią reklamową), to powinien on zwrócić się o podanie tego, kto jest jego właścicielem, ponieważ nie w każdym przypadku można od razu absolutnie stwierdzić, iż właścicielem reklamy jest podmiot, którego taka reklama dotyczy ${ }^{29}$. Równocześnie dostrzega się również, że zasadne zdaje się stwierdzenie, że podmiotem ponoszącym odpowiedzialność administracyjną z tego tytułu będzie podmiot zajmujący pas drogowy, przy czym co do zasady będzie to podmiot na rzecz którego reklama ta została zamontowana [...] nie jest bowiem istotne, kto fizycznie umieścił reklamę w obszarze pasa drogowego. Istotne jest, kto jest zleceniodawcą i na czyją rzecz reklama została umieszczona ${ }^{30}$.

Co więcej, dostrzega się, że dla uznania danego podmiotu za stronę postępowania nie ma znaczenia fakt, czy poprzez umieszczenie w pasie drogowym reklamy osiągnął on jakąkolwiek korzyśść ${ }^{31}$.

Jeżeli zajęcia pasa drogowego polega na prowadzeniu w nim robót, to za stronę postępowania nie można uznać bezpośredniego ich wykonawcę, lecz inwestora, na rzecz którego takie roboty są wykonywanie w sytuacji, w której inwestor uzyskał zezwolenie na zajęcie pasa drogowego, a następnie przekroczył termin tego zajęcia jako podmiot mający własny interes prawny do prowadzenia robót w pasie drogowym, winien on być podmiotem decyzji o wymierzeniu kary pieniężnej z tego tytułu. Wykonawca takich robót zazwyczaj nie realizuje ich bowiem we własnym

\footnotetext{
${ }^{26}$ Wyrok NSA z dnia 18 października 2017 r., II GSK 3311/15, LEX nr 2417458.

27 Wyrok NSA z dnia 13 marca 2012 r., II GSK 138/11, LEX nr 1218995, wyrok WSA w Warszawie z dnia 14 czerwca 2017 r., VI SA/Wa 850/16, LEX nr 2345740.

28 Wyrok NSA z dnia 16 marca 2009 r., II GSK 832/08, LEX nr 529876.

${ }^{29}$ Wyrok WSA w Gorzowie Wielkopolskim z dnia 19 maja 2010 r., II SA/Gl 57/10, LEX nr 674120 .

${ }^{30}$ Wyrok WSA w Warszawie z dnia 10 kwietnia 2017 r., VI SA/Wa 2178/16, LEX nr 2288507.

31 Wyrok WSA w Warszawie z dnia 13 grudnia 2012 r., VI SA/Wa 1661/12, LEX nr 1451545.
} 
imieniu i na własną rzecz, lecz na zlecenie i w imieniu inwestora, stąd nie posiada $\mathrm{w}$ takim postępowaniu interesu prawnego $\mathrm{w}$ rozumieniu art. 18 k.p.a. ${ }^{32}$

Jeżeli natomiast pomiędzy podmiotem zajmującym pas drogowy a podmiotem trzecim została zawarta umowa cywilnoprawna, to nie może ona w żaden sposób kształtować powstałego pomiędzy zarządcą drogi a zajmującym pas drogowy podmiotem stosunku administracyjnoprawnego, ponieważ kwestii legitymacji do bycia stroną w postępowaniu o nałożenie sankcji o charakterze publicznoprawnym, wynikającej z bezwzględnie obowiązujących przepisów prawa, nie jest władna zmienić umowa. Umowa, jako instrument prawa cywilnego, co do zasady, wiąże tylko strony, które ją zawarł, nie zaś nie będący jej stroną organ administracji publicznej3.

Jednocześnie dopuszczalne jest, by postanowienia umowy cywilnoprawnej skutecznie kształtowany stan faktyczny danej sprawy, gdyż umowa cywilnoprawna wiąże jedynie strony i nie można nią kształtować stosunków administracyjnoprawnych, co nie oznacza, że nie może w sposób prawnie skuteczny kształtować stanu faktycznego sprawy, rzeczywistej sytuacji jej stron, że na jej podstawie nie może dojść do przeniesienia faktycznego władztwa nad danym przedmiotem, osoba, która to władztwo przejęła nie może być tym, który dokonuje faktycznego zajęcia pasa drogowego, a w konsekwencji podmiot ten ponosi odpowiedzialność administracyjną ${ }^{34}$.

\section{PODSUMOWANIE}

Prawidłowe ustalenie stron postępowania jest wyjątkowo podniosłym obowiązkiem powierzonym organom administracji publicznej. Niewłaściwe ustalenie kręgu podmiotów, które legitymują się w danej sprawie interesem prawnym bądź obowiązkiem, a w konsekwencji pozbawienie którejkolwiek z nich prawa do uczestniczenia w tym postępowaniu bądź skierowanie decyzji administracyjnej do podmiotu niebędącego stroną, niezaprzeczalnie stanowić może kwalifikowane naruszenie procedury administracyjnej mogące mieć wpływ na wynik postępowania (i tym samym być podstawą do wznowienia postępowania bądź stwierdzenia nieważności takiego rozstrzygnięcia). Brak jednoznacznego wskazania w przepisach u.d.p. cech charakteryzujących podmioty, które należałoby uznać za stronę postępowania w sprawie nałożenia kary pieniężnej za zajęcie pasa drogowego bez

32 Wyrok WSA w Poznaniu z dnia 25 lutego 2015 r., III SA/Po 1005/13, LEX nr 1440794. Również wyrok WSA w Gliwicach z dnia 13 kwietnia 2012 r., II SA/G1 97,12, LEX nr 1145763.

${ }_{33}$ Wyrok NSA z dnia 3 grudnia 2008 r., II GSK 560/08, LEX nr 518207.

${ }^{34}$ Wyrok WSA w Gorzowie Wielkopolskim z dnia 28 lutego 2018 r., II SA/Go 1162/17, LEX nr 2455892. 
zezwolenia należy ocenić pozytywnie. Mnogość sytuacji i ich możliwych konfiguracji bezprawnego zajęcia pasa drogowego nie powinna być ograniczana przez sztywne określanie przymiotów podmiotów podlegających odpowiedzialności administracyjnej na podstawie art. 40 ust. 12 u.d.p. Przyjęta przez ustawodawcę konstrukcja pozwala zarządcom dróg na elastyczne ustalanie podmiotów faktycznie zajmujących pas drogowy w zależności od ustalonego w konkretnej sprawie stanu faktycznego. Niedopuszczalne bowiem byłoby, przykładowo, wskazanie, iż stroną powinien być podmiot legitymujący się prawem własności do obiektu (np. reklamy) umieszczonego w pasie drogowym, ponieważ nie pozwalałoby zarządcy drogi na uwzględnienie stosunków cywilnoprawnych istniejących pomiędzy jej właścicielem, a osobą zlecającą jej umieszczenie. Podobnie przedstawiałaby się sytuacja, w której za stronę powinien zostać uznany na wstępie podmiot, który w ocenie zarządcy drogi powinien w danej sytuacji wystąpić o zezwolenie na zajęcie pasa drogowego czy też prowadzi w pasie drogowym jakiekolwiek roboty. Analizując orzeczenia sądów administracyjnych odnoszące się do problematyki stron postępowania w sprawach o nałożenie kary pieniężnej na podstawie art. 40 ust. 12 u.d.p. odnieść można wrażenie, że zarządcy dróg niekiedy działają zupełnie automatycznie, bez jakiejkolwiek chęci dążenia do ustalenia prawdy obiektywnej mając na względnie tylko i wyłącznie cel fiskalny. Dlatego też słuszne wydaje się, że zarządcy dróg powinni dążyć do wypracowania takich standardów, dzięki którym kary za zajęcie pasa drogowego bez zezwolenia nakładane będą po rzetelnym i starannym ustaleniu strony, która faktycznie dopuściła się deliktu administracyjnego.

\section{BIBLIOGRAFIA}

Borkowski J. (red.), Kodeks postępowania administracyjnego. Komentarz, Warszawa 1989.

Borkowski J., Adamiak B., Kodeks postepowania administracyjnego, Warszawa 2017.

Hauser R., Wierzbowski M. (red.), Kodeks postępowania administracyjnego, Warszawa 2017.

Hauser Z., Niewiadomski Z., Wróbel A. (red.), System prawa administracyjnego t.7, Warszawa 2012.

Iserzon E., Starościak J., Kodeks postępowania administracyjnego. Komentarz, Warszawa 1970.

Kruk E., Sankcja Administracyjna, Lublin 2013.

Maciejko W., Zabrniak P., Ustawa o drogach publicznych. Komentarz, Warszawa 2010.

Sobieralski K., Kara za zajęcie pasa drogowego, Wrocław 2015.

Stahl M., Lewicka R., Lewicki M. (red.), Sankcje administracyjne. Blaski i cienie, Warszawa 2011.

Wincenciak M., Sankcje administracyjne i procedura ich wymierzania, Warszawa 2008.

Wróbel A., Jaśkowska M. (red.), Kodeks postępowania administracyjnego. Komentarz, Warszawa 2016.

Wyrok TK z dnia 1 marca 1994 r., U 7/93, Legalis nr 10199.

Wyrok TK z dnia 31 marca 2006 r., SK 75/06, Legalis nr 95189.

Wyrok NSA z dnia 3 grudnia 2008 r., II GSK 560/08, LEX nr 518207.

Wyrok NSA z dnia 16 marca 2009 r., II GSK 832/08, LEX nr 529876.

Wyrok NSA z dnia 10 marca 2011 r., II GSK 244/10, LEX nr 1244617. 
wyrok NSA z dnia 29 czerwca 2011 r., II GSK 648/10, Legalis nr 372982. Wyrok NSA z dnia 13 marca 2012 r., II GSK 138/11, LEX nr 1218995. Wyrok NSA z dnia 9 czerwca 2015 r., II GSK 1023/14, Legalis nr 1311855. wyrok NSA z dnia 23 czerwca 2015 r., II GSK 1377/14, LEX nr 1982581. Wyrok NSA z dnia 18 października 2017 r., II GSK 3311/15, LEX nr 2417458.

Wyrok WSA w Łodzi z dnia 22 października 2008 r., III SA/Łd 272/08, LEX nr 511394. Wyrok WSA w Gorzowie Wielkopolskim z dnia 19 maja 2010 r., II SA/G1 57/10, LEX nr 674120. Wyrok WSA we Wrocławiu z dnia 21 lipca 2011 r., III SA/Wr 227/11, LEX nr 950752. Wyrok WSA w Olsztynie z dnia 8 marca 2012 r., II SA/O1 1049/11, LEX nr 1138650. Wyrok WSA w Gliwicach z dnia 13 kwietnia 2012 r., II SA/G1 97,12, LEX nr 1145763. Wyrok WSA w Warszawie z dnia 13 grudnia 2012 r., VI SA/Wa 1661/12, LEX nr 1451545. Wyrok WSA w Olsztynie z dnia 24 czerwca 2014 r., II SA/O1 419/14, Legalis nr 1152542. Wyrok WSA w Łodzi z dnia 14 sierpnia 2014 r., III SA/Ld 314/14, LEX nr 1502814. Wyrok WSA w Poznaniu z dnia 14 stycznia 2015 r., III SA/Po 537/14, Legalis nr 1198668. Wyrok WSA w Szczecinie z dnia 15 stycznia 2015 r., II SA/Sz 993/14, LEX nr 1625552. Wyrok WSA w Poznaniu z dnia 25 lutego 2015 r., III SA/Po 1005/13, LEX nr 1440794. Wyrok WSA w Warszawie z dnia 10 kwietnia 2017 r., VI SA/Wa 2178/16, LEX nr 2288507. Wyrok WSA w Warszawie z dnia 14 czerwca 2017 r., VI SA/Wa 850/16, LEX nr 2345740. Wyrok WSA w Gorzowie Wielkopolskim z dnia 21 czerwca 2017 r., LEX nr 2313720. Wyrok WSA w Kielcach z dnia 20 lipca 2017 r., II Sa/Ke 289/17, LEX nr 2359721. Wyrok WSA w Warszawie z dnia 29 listopada 2017 r., VI SA/Wa 1061/17, LEX nr 2419335. Wyrok WSA w Gorzowie Wielkopolskim z dnia 28 lutego 2018 r., II SA/Go 1162/17, LEX nr 2455892.

\section{SUMMARY}

The entity who perpetrated an unlawful occupation of the road lane bears the administrative responsibility in the form of administrative monetary penalty. One of the first road administrator's activities before initiation of proceedings timing to impose a penalty is determination of parties. In this article author discussed the issue of determination of parties in accordance with article 40 paragraph 12 of the Act of the Public Roads in the spotlight of administrative courts rulings.

Key words: administrative monetary penalty, public roads, party to proceedings. 